Agro-Science Journal of Tropical Agriculture, Food, Environment and Extension Volume 12 Number 3 September 2013 pp. 15 - 24

ISSN 1119-7455

\title{
GROWTH AND YIELD OF ONION AS INFLUENCED BY ORGANIC AND INORGANIC FERTILIZER IN EDO RAINFOREST OF NIGERIA
}

\author{
Falodun ${ }^{2}$ E.J, Ehigiator ${ }^{2}$ J.O and ${ }^{a}$ Egharevba $^{1}$ R.K.A. \\ Department of Crop Science, Faculty of Agriculture, University of Benin, Nigeria. \\ Department of Soil Science, Faculty of Agriculture, University of Benin, Nigeria. \\ *Corresponding author: ehizogie.falodun@uniben.edu
}

\begin{abstract}
The current study was to determine the effect of NPK 15:15:15 and poultry manure on the growth and yield of onion plant (Allium cepa L.). Two field experiments were carried out at the Faculty of Agriculture Teaching and Research Farm, University of Benin during the 2010/2011 and 2011/2012 dry croppping seasons of October-March. The experiment was a factorial combination of four levels of NPK 15:15:15 inorganic fertilizer at 0, 40,80 and $120 \mathrm{~kg}$ /ha NPK and four levels of poultry manure at 0, 5, 10 and 15t/ha laid out in a randomized complete block design (RCBD) with three replications. Each replicate had 16 plots making it a total of 48 plots. Data were collected on growth and yield characters and analysed. Results of this study indicated that there was a significant interaction between the poultry manure and NPK 15:15:15 fertilizer on some growth and yield attributes. Application rates of $80 \mathrm{~kg} / \mathrm{ha}$ NPK 15:15:15 in combination with 15t/ha poultry manure enhanced the growth and yield of onion in terms of crop growth rate, chlorophyll content, harvest index and individual bulb weight of onion and significantly produced the highest yield of $(29.55 \mathrm{t} / \mathrm{ha})$ in 2011/2012 and $(28.17 \mathrm{t} / \mathrm{ha})$ in 2012/2013. However, application rates of $120 \mathrm{~kg} / \mathrm{ha}$ and $15 \mathrm{t} / \mathrm{ha}$ produced the highest (7.06 and $6.89 \mathrm{t} / \mathrm{ha}$ ) shoot yield for 2011/2012 and 2012/2013 respectively.
\end{abstract}

Keywords: onion, manure, harvest index, crop growth rate,

\section{INTRODUCTION}

A system that integrates different practices of soil fertility programme is required for optimum growth and development of crops and this include the use of mineral fertilizers and organic manures. Decline in soil fertility is especially serious in the tropical regions where the soil lacks adequate plant nutrients and organic matter due to leaching and erosion of topsoil by intense rainfall. The complementary application reduces the dependence of the farmer on inorganic fertilizer. It also reduces the exposure of the soil to the consequences of inorganic fertilizer application. Jeyathilake et al. (2006) have observed that the nutrient use efficiency of a crop is increased through a combined application of organic manure and mineral fertilizer.

Organic manures alone are unable to give economic yield in some crops and it is vital to find appropriate combination of inorganic and organic manure to obtain financially viable yield of crops. Jeyathilake et al. (2006) stated that integrated use of organic manure and chemical fertilizers resulted in onion yield increase in comparison with the exclusive application of chemical fertilizers. Replenishing the nutrients removed by crops with recycling of agricultural wastes into the soil can sustain soil and crop productivity (Paul and Mannan 2006). There is ample opportunity for nutrient recycling in the tropics where huge

http://dx.doi.org/10.4314/as.v12i3.3 
amounts of agricultural wastes are generated ye Growth and Yield of Onion as Influenced By Organic and Inorganic Fertilizer

integrateu nument Illanagentent packages IU sustaining the changing needs of intensive vegetable production in the tropics. Combine use of organic wastes and mineral fertilizer is reported to reduce the cost and amount of fertilizer required by crops (International Atomic Energy Agency [IAEA] 2003; Krupnik et al., 2004). This practice as documented by Dobermann and Cassman (2004) is also known to improve nutrient use efficiency and chemical and nutritional quality of crops. Renewable management of organic sources of $\mathrm{N}$ through use of agricultural waste materials would improve the quality of the environment and soil health.

Combination of organic and inorganic fertilizers could produce better yields than organic or inorganic alone because inorganic fertilizers release the nutrients quickly and fulfill the plants need at the appropriate time, while the organic manure being slow releasing recaptures the growth rate in latter stages. This combination could possibly increase yield and reduce the cost of production in onion cultivation.

Continuous use of inorganic fertilizers as reported by Jeyathiake et al., (2006) resulted in deficiency of micronutrients, imbalance in soil physiochemical properties and unsustainable crop production. As a result, farmers are currently changing from conventional to organic farming systems which used no synthetic fertilizers and pesticides (Colla et al., 2002). This could also be due to the continuous increase of prices of synthetic chemicals in the world market. However, organic,. like poultry manures alone are unable to give economic yield because it discharges nutrients very slowly to the plants and these nutrients are not directly absorbed by plants, therefore plants are unable to access required amount of nutrients in the critical yield forming period. Therefore it is vital to find appropriate combinations of inorganic and organic manure to obtain financially viable yield of crops (Jeyathilake et al., 2006).

According to Bayu et al. (2010), Inorganic fertilizer treated plants exhibited quick growth of leaves at the early stage of onion plants because the rate of release of nutrients are much higher, which was recompensed by the organic manure in the later stages and this contributed to the final yield, thus combination of organic and inorganic fertilizer could produce better yields than organic or manure alone. Combine use of fertilizers have a positive effects on plants due to the better availability of soil nutrients that produce properties, which is 1 (1998) researched uIe entect on $\angle \mathrm{v}, 4 \mathrm{v}$, ov und animal manure doses, NPK (75: 50:100 kg / ha) inorganic fertilizer and combination of these and reported higher increase with their combinations. Sharma et al (2003) revealed that 125,33 and $50 \mathrm{~kg} / \mathrm{ha} \mathrm{N} \mathrm{P}$ and $\mathrm{K}$ in combination with 0,10 and 20t/ha manure increased onion yield and nutrient uptake. According to Ouda and Mahadeen (2008), leaf chlorophyll content was significantly higher when inorganic fertilizer in combination with poultry manure were used compared with using organic or inorganic fertilizer alone. Application dose of $80 \mathrm{t} / \mathrm{ha}$ poultry manure in combination with $60 \mathrm{~kg} / \mathrm{ha} \mathrm{N}, \mathrm{P}$ and $\mathrm{K}$ induced the highest leaf chlorophyll content, while the lowest chlorophyll content was obtained by control treatment. A promotion effect of organic and inorganic fertilizers on chlorophyll contents might be attributed to the fact that $\mathrm{N}$ is a constituent of chlorophyll molecule. This was again emphasized by Arisha and Bradisi (1999); Al-Tarawneh (2005) that nitrogen is the main constituent of all amino acids in protein and lipids that act as a structural compounds of the chloroplast. Therefore, utilization of locally produced manures in combination with inorganic fertilizer at the recommended dose by vegetable production operations may increase crop. The objective of this study therefore was to investigate the optimum combination rate of NPK 15:15:15 and poultry manure for the production of onion in Edo state.

\section{MATERIALS AND METHODS}

The Experiments were carried out in the 2011/2012 and 2012/2013 dry season at the Teaching and Research Farm of the University of Benin, Ugbowo Campus, Benin-City, in Edo State and Lies within the geographical coordinates of longitude $5^{0,} 04^{\prime \prime}$ and $06^{\circ} 43 " \mathrm{E}$ and latitude $05^{\circ}$ $44^{\prime \prime} \mathrm{N}$ and $07^{\circ} 34$ " $\mathrm{N}$. The climate is tropical and the vegetation is low-land rainforest in the south (with mean annual rainfall of $2300 \mathrm{~mm}$ ) to guinea savanna in Edo North with $1400 \mathrm{~mm}$ mean rainfall. Prior to analysis, the soil samples were air dried and crushed to pass through a $2 \mathrm{~mm}$ sieve. Soil $\mathrm{pH}$ was determined using a $\mathrm{pH}$ meter. Organic carbon was determined by (Walkley and Black, 1962) wet oxidation method as modified by Jackson (1969). Total nitrogen was obtained by macro Kjeldahl methods as modified by Jackson (1969). Available $\mathrm{P}$ was extracted by Bray I method (Bray and Kurtz, 1945) and the $\mathrm{P}$ was estimated by the blue colour method of Murphy and Riley (1962). 
Falodun E.J, Ehigiator J.O and ${ }^{\mathrm{a}}$ Egharevba R.K.A.

Exchangeable $\mathrm{K}$ and $\mathrm{Na}$ were determined using flame photometer, and $\mathrm{Ca}$ and $\mathrm{Mg}$ using the Atomic Absorption Spectrophotometer. The result of the soil and poultry manure analysis is as presented in Table 1 .

The experiment was laid out as a $4 \times 4$ factorial arrangement fitted into a randomized complete block design (RCBD) in three replications. The treatments comprised of combination of four levels of organic fertilizer application $\left(0,5,10\right.$ and 15 tha $\left.^{-1}\right)$ in combination with four levels of inorganic fertilizer at $(0,40,80$ and $120 \mathrm{~kg} / \mathrm{ha}$ of NPK 15:15:15). The land was cleared with the debris worked into the soil with a hoe. Beds for planting were prepared and onion seeds (Kano red) were sown on 25/10/2011 and $25 / 10 / 2012$ for two consecutive field trials in drills spaced at $8 \mathrm{~cm}$ apart in the nursery and observed for germination after 14 days of sowing (Akoun, 2004). Two weeks before transplanting, the field was marked out and beds of $1 \times 1 \mathrm{~m}$ spaced at $0.5 \mathrm{~m}$ apart were prepared. Each replicate had 16 beds for a total of 48 beds. The treatment were assigned to each experimental unit using a table of random numbers. Onion transplanting to the field was done on 13 December 2011 and 2012 for two consecutive field trials when seedlings were seven weeks after sowing and at about $14 \mathrm{~cm}$ tall. Plots were mulched to conserve soil moisture and suppress weeds.

Poultry manure at $0,5,10$ and $15 \mathrm{t} / \mathrm{ha}$ were applied two weeks before transplanting to the respective plots depending on the treatment. The inorganic fertilizer application at $(0,40,80$ and $120 \mathrm{~kg} / \mathrm{ha}$ of NPK 15:15:15 compound fertilizer were applied in split applications. The first dose was applied two weeks after transplanting and the remaining half at six weeks after transplanting by side placement along the rows to the respective plots depending on the treatment. The field was weeded manually using hoe. A total of three hand weedings were done at 3,6 and 8 weeks after transplanting. Insects were handpicked when necessary. Data collection started four weeks after transplanting. Four plants were randomly selected from each plot and tagged for the purpose of collecting data for plant height, number of leaves, chlorophyll content, crop growth rate individual bulb weight, bulb diameter, bulb length, fleshy thickness, harvest index, bulb yield and total fresh yield per hectare. The data obtained were subjected to statistical analysis of variance (ANOVA) using SAS following the model for factorial experiment in a randomized complete block design and means separated by Duncan Multiple Range Test (DMRT).

\section{RESULTS \\ Crop growth rate (CGR)}

Increase in the rate of fertilizer application increased the crop growth rate of onion plant up to $80 \mathrm{~kg} \mathrm{ha}^{-1}$ NPK. A further increase in inorganic fertilizer to $120 \mathrm{kgha}^{-1}$ depressed the growth rate significantly. Plants treated with $80 \mathrm{kgha}^{-1}$ produced the highest growth rate and this was followed by plants which received either 40 or $120 \mathrm{kgha}^{-1}$ which were at par and significantly increased CGR above the controls treatment which produced significantly lowest CGR. Poultry manure application increased the CGR of onion plant up to $15 \mathrm{~kg} \mathrm{ha}^{-1}$. Plants treated with $15 \mathrm{~kg} \mathrm{ha}^{-}$ poultry manure resulted in the highest CGR and this was significantly increased above other treatments. This increase was followed by those plants which received $10 \mathrm{~kg} \mathrm{ha}^{-1}$ and then $5 \mathrm{~kg} \mathrm{ha}^{-1}$ and the least CGR was observed in the control (Table 2).

NPK by poultry manure interaction was highly significant. In Table 4, when the same level of NPK was examined across the poultry manure levels, it was observed that at $0 \mathrm{~kg} \mathrm{ha}^{-1} \mathrm{NPK}$, each level of poultry manure significantly increased CGR. At $40 \mathrm{~kg} \mathrm{ha}^{-1} \mathrm{NPK}$, the CGR produced was the same at 10 and $15 \mathrm{t} \mathrm{ha}^{-1}$ poultry manure and were significantly higher than that produced at 0 and $5 \mathrm{t} \mathrm{ha}^{-1}$. However, $5 \mathrm{t} \mathrm{ha}^{-1}$ increased CGR above the $0 \mathrm{tha}^{-1}$ application rate.

At $80 \mathrm{~kg} \mathrm{ha}^{-1} \mathrm{NPK}$, each level of poultry manure increased CGR and the highest CGR was produced at $15 \mathrm{tha}^{-1}$ poultry manure, followed by $10 \mathrm{tha}^{-1}$, then $5 \mathrm{tha}^{-1}$ and the lowest was at the control. At $120 \mathrm{~kg} \mathrm{ha}^{-1}$ NPK, CGR increased significantly up to $5 \mathrm{t} \mathrm{ha}^{-1}$ and a further increase in poultry manure up to 10 and $15 \mathrm{tha}^{-1}$ did not affect CGR.

When the same level of poultry manure was examined across the NPK levels, there was a significant increase in CGR, increase in NPK level from 0 to $80 \mathrm{~kg} \mathrm{ha}^{-1}$ NPK resulted in increase in CGR. A further increase in NPK level to $120 \mathrm{~kg}$ $\mathrm{ha}^{-1}$ did not affect the CGR. At $5 \mathrm{t} \mathrm{ha}^{-1}$ poultry manure, there was a significant increase in CGR when NPK was increased from 0 to $120 \mathrm{~kg} \mathrm{ha}^{-1}$. The difference between the control and $120 \mathrm{~kg} \mathrm{ha}^{-1}$ was significant. At $10 \mathrm{tha}^{-1}$ and $15 \mathrm{t} \mathrm{ha}^{-1}$ poultry manure, each increase in NPK level significantly increased CGR up to $80 \mathrm{~kg} \mathrm{ha}^{-1}$, but a further increase to $120 \mathrm{~kg} \mathrm{ha}^{-1}$ significantly decreased CGR The highest CGR was produced at $80 \mathrm{~kg} \mathrm{ha}^{-1}$ in combination with $15 \mathrm{t} \mathrm{ha}^{-1}$ poultry manure. 
Table 1: Physical and chemical properties of poultry manure and soil of the experimental ite pre plant and post harvest

\begin{tabular}{|c|c|c|c|}
\hline \multirow[t]{2}{*}{ Soil properties } & \multicolumn{2}{|c|}{ Experimental site } & \multirow[t]{2}{*}{ poultry manure } \\
\hline & Pre & Post & \\
\hline $\mathrm{pH}\left(\mathrm{H}_{2} \mathrm{O}\right)$ & 4.80 & 5.26 & 6.40 \\
\hline 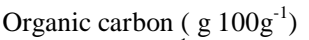 & 0.40 & 0.73 & 23.00 \\
\hline Total $N\left(\mathrm{~g} 100 \mathrm{~g}^{-1}\right)$ & 0.05 & 0.03 & 2.13 \\
\hline Total P $\left(\mathrm{mg} \mathrm{kg}^{-1}\right)$ & 18.9 & 14.7 & 4.30 \\
\hline $\mathrm{K}\left(\mathrm{cmol} \mathrm{kg}^{-1}\right)$ & 0.19 & 0.12 & 1.12 \\
\hline $\mathrm{Ca}\left(\mathrm{cmol} \mathrm{kg}^{-1}\right)$ & 1.15 & 0.81 & 3.76 \\
\hline $\mathrm{Mg}\left(\mathrm{cmol} \mathrm{kg}^{-1}\right)$ & 0.74 & 0.56 & - \\
\hline $\operatorname{Mn}\left(\mathrm{cmol} \mathrm{kg}^{-1}\right)$ & - & - & 1.14 \\
\hline $\mathrm{Zn}\left(\mathrm{cmol} \mathrm{kg}^{-1}\right)$ & - & - & 0.13 \\
\hline $\mathrm{Fe}\left(\mathrm{cmol} \mathrm{kg}^{-1}\right)$ & - & - & 3.27 \\
\hline $\mathrm{Na}\left(\mathrm{cmol} \mathrm{kg}^{-1}\right)$ & - & - & 0.17 \\
\hline Sand $\left(\mathrm{g} \mathrm{kg}^{-1}\right)$ & 752.1 & 756.0 & - \\
\hline Clay $\left(\mathrm{g} \mathrm{kg}^{-1}\right)$ & 198.0 & 163.4 & - \\
\hline Silt $\left(\mathrm{g} \mathrm{kg}^{-1}\right)$ & 46.0 & 48.2 & - \\
\hline Textural class & \multicolumn{2}{|c|}{ Sandy loam } & - \\
\hline
\end{tabular}

Table 2: Effect of NPK 15:15:15 fertilizer and poultry manure on crop growth rate (CGR) $\mathrm{gm}^{-2} \mathbf{w k}^{-1}$, Chlorophyll content $(\mathrm{mg} \mathrm{g-1})$, Bulb diameter $(\mathrm{cm})$ and Bulb length $(\mathrm{cm})$ of onion (2011/2012) and 2012/2013 dry cropping season

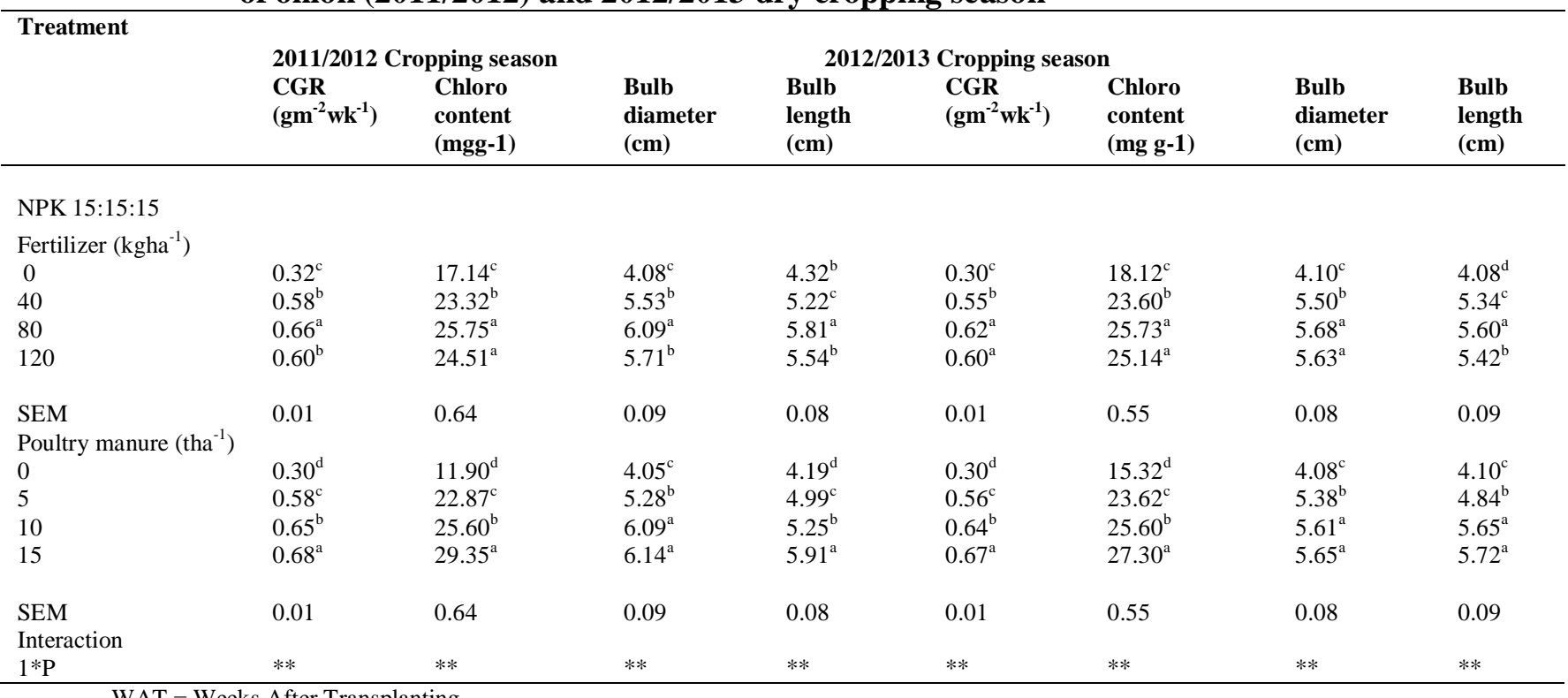

WAT $=$ Weeks After Transplanting

Means followed by the same letter in a column are not significantly different at $5 \%$ level of probability. ** Significant at $1 \%$ level of probability 


\section{Chlorophyll content of leaves}

Increase in the rate of application of inorganic fertilizer resulted in an increase in chlorophyll content up to $80 \mathrm{~kg} \mathrm{ha}^{-1}$ NPK. A further increase to $120 \mathrm{~kg} \mathrm{ha}^{-1}$ of NPK did not result in a significant increase. 80 and $120 \mathrm{~kg} \mathrm{ha}^{-1}$ NPK were at par and significantly increased leaf chlorophyll above the control and $40 \mathrm{~kg} \mathrm{ha}^{-1}$ application. However, $40 \mathrm{~kg} \mathrm{ha}{ }^{-1}$ NPK significantly increased chlorophyll content above the control treatment which received no fertilizer and significantly produced the least chlorophyll content (Table 2). On the other hand, the effect of poultry manure on chlorophyll content was highly significant. $15 \mathrm{t} \mathrm{ha}^{-1}$ poultry manure significantly increased chlorophyll content above all other treatments, this was followed by plants which received $10 \mathrm{tha}^{-1}$ poultry manure and then $5 \mathrm{tha}^{-1}$ poultry manure. The control produced the least chlorophyll content for onion leaves.

The NPK by poultry manure interactions was highly significant. In Table 3, when the same level of NPK was examined across varying poultry manure levels, it was observed that chlorophyll content increased with increase in poultry manure up to $10 \mathrm{t} \mathrm{ha}^{-1}$, with 10 and $15 \mathrm{t} \mathrm{ha}^{-1}$ poultry manure producing similar chlorophyll content. At $40 \mathrm{~kg} \mathrm{ha}^{-1} \mathrm{NPK}, 5$ and $10 \mathrm{tha}^{-1}$ were similar and significantly higher than the control, but $15 \mathrm{t} \mathrm{ha}^{-1}$ poultry manure produced higher chlorophyll content than the other poultry manure values. At $80 \mathrm{~kg} \mathrm{ha}^{-1} \mathrm{NPK}$, each increase in poultry manure levels significantly increased chlorophyll with $15 \mathrm{t}$ $\mathrm{ha}^{-1}$ poultry manure producing the highest chlorophyll content. At $120 \mathrm{~kg} \mathrm{ha}^{-1}$ NPK, chlorophyll increased up to $5 \mathrm{t} \mathrm{ha}^{-1}$ poultry manure and a further increase did not affect the chlorophyll content (Table 3). When the same level of poultry manure was examined across the NPK levels, it was observed that at 0 and $5 \mathrm{t} \mathrm{ha}^{-1}$ poultry manure, 40,80 and $120 \mathrm{~kg} \mathrm{ha}^{-1}$ NPK produced similar chlorophyll content but were significantly higher than the control. At $10 \mathrm{t} \mathrm{ha}^{-1}$ poultry manure, increase in NPK increased the chlorophyll content up to $80 \mathrm{~kg} \mathrm{ha}^{-1}$ and a further increase to $120 \mathrm{~kg} \mathrm{ha}^{-1}$ NPK producing similar chlorophyll but significantly higher than the control. At $15 \mathrm{t} \mathrm{ha}^{-1}$ poultry manure, $80 \mathrm{~kg} \mathrm{ha}^{-1}$ NPK produced the highest leaf chlorophyll and this was followed by $40 \mathrm{~kg} \mathrm{ha}^{-1}$ NPK and the 120 $\mathrm{kg} \mathrm{ha}^{-1}$, the least chlorophyll content was produced at the control (Table 3).

Table 3: Interactions between NPK 15:15:15 fertilizer and poultry manure on chlorophyll content $\left(\mathrm{gm}^{-2} \mathrm{wk}^{-1}\right)$ and crop growth rate (CGR) $\mathrm{gm}^{-2} \mathrm{wk}^{-1}$ of onion $(2011 / 2012)$ and 2012/2013 dry cropping season

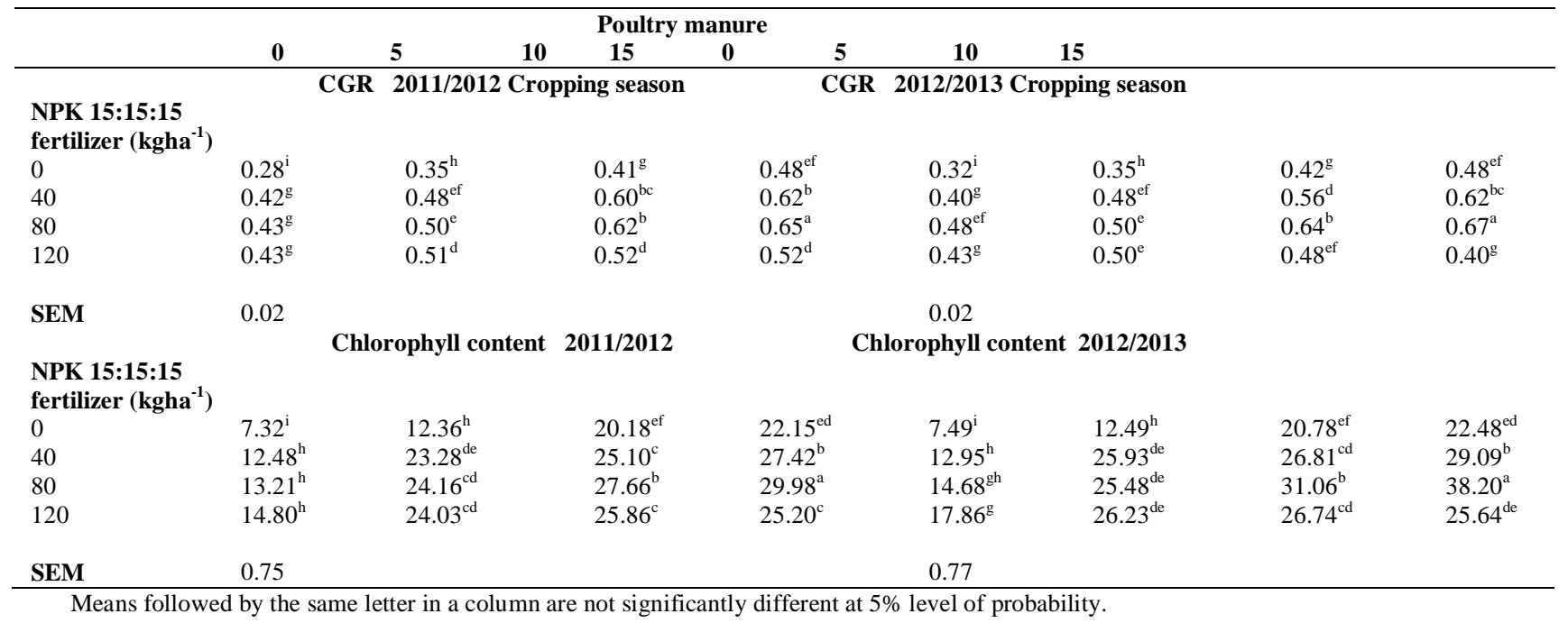




\section{Yield characters Bulb diameter}

Increase in the rate of application of NPK fertilizer resulted in a significant increase in bulb diameter up to $80 \mathrm{~kg} \mathrm{ha}^{-1}$ NPK (Table 4). A further increase to $120 \mathrm{~kg} \mathrm{ha}^{-1}$ application depressed the bulb diameter. Plants treated with $80 \mathrm{~kg} \mathrm{ha}^{-1}$ NPK produced the highest bulb diameter and was significantly higher than other treatments. Plants treated with either 40 or $120 \mathrm{~kg} \mathrm{ha}^{-1}$ NPK were at par and were significantly increased above the control treatment.

The effect of poultry manure on bulb diameter was highly significant. 10 and $15 \mathrm{t} \mathrm{ha}^{-1}$ poultry manure significantly increased bulb diameter above the control and $5 \mathrm{tha}^{-1}$ poultry manure. The control produced the least value for bulb diameter. In Table 4, the NPK X Poultry manure interaction was highly significant. When the same level of NPK was examined across the poultry manure levels, it was observed that at $0 \mathrm{~kg} \mathrm{ha}^{-1} \mathrm{NPK}$, bulb diameter increased with increase in poultry manure up to $10 \mathrm{tha}^{-1}$.

At $40 \mathrm{~kg} \mathrm{ha}^{-1} \mathrm{NPK}$, increase in poultry manure increased bulb diameter up to $15 \mathrm{t} \mathrm{ha}^{1}$, with 10 and 15 tha $^{-1}$ poultry manure producing similar bulb diameter. At $80 \mathrm{~kg} \mathrm{ha}^{-1}$ NPK, bulb diameter increased significantly with increase in poultry manure up to $10 \mathrm{t} \mathrm{ha}^{-1}$ and a further increase to $15 \mathrm{t} \mathrm{ha}^{-1}$ did not affect bulb diameter. At $120 \mathrm{~kg} \mathrm{ha}^{-1}$ NPK, bulb diameter increased significantly up to $5 \mathrm{tha}^{-1}$ a further increase did not affect bulb diameter was produced at $80 \mathrm{~kg} \mathrm{ha}^{-}$ ${ }^{1}$ poultry manure.

When the same level of poultry manure was examined across the NPK levels, it was observed that at $0 \mathrm{t} \mathrm{ha}^{-1}$ poultry manure bulb diameter increased significantly At $5 \mathrm{t} \mathrm{ha}^{-1}$ poultry manure, bulb diameter increased with increase in NPK up to $80 \mathrm{kgha}^{-1}$ NPK but there was no further increase at $120 \mathrm{k} \mathrm{gha}^{-1}$ NPK. At 10 and $15 \mathrm{t} \mathrm{ha}^{-1}$ poultry manure, each increase in NPK increased bulb diameter from 0 to $80 \mathrm{~kg} \mathrm{ha}^{-1}$. A further increase to $120 \mathrm{~kg} \mathrm{ha}^{-1}$ NPK decreased the bulb diameter significantly, with 40 and $120 \mathrm{~kg} \mathrm{ha}^{-1}$ NPK producing similar bulb diameter. The highest bulb diameter was produced at $80 \mathrm{~kg} \mathrm{ha}^{-1}$ NPK in combination with either $10 \mathrm{t} \mathrm{ha}^{-1}$ or $15 \mathrm{t} \mathrm{ha}^{-1}$ poultry manure. However, $5 \mathrm{t} \mathrm{ha}^{-1}$ poultry manure increased bulb diameter significantly above the control treatment.

Table 4: Interactions between NPK 15:15:15 fertilizer and poultry manure on bulb diameter and bulb length of onion (2011/2012) and 2012/2013 dry cropping season

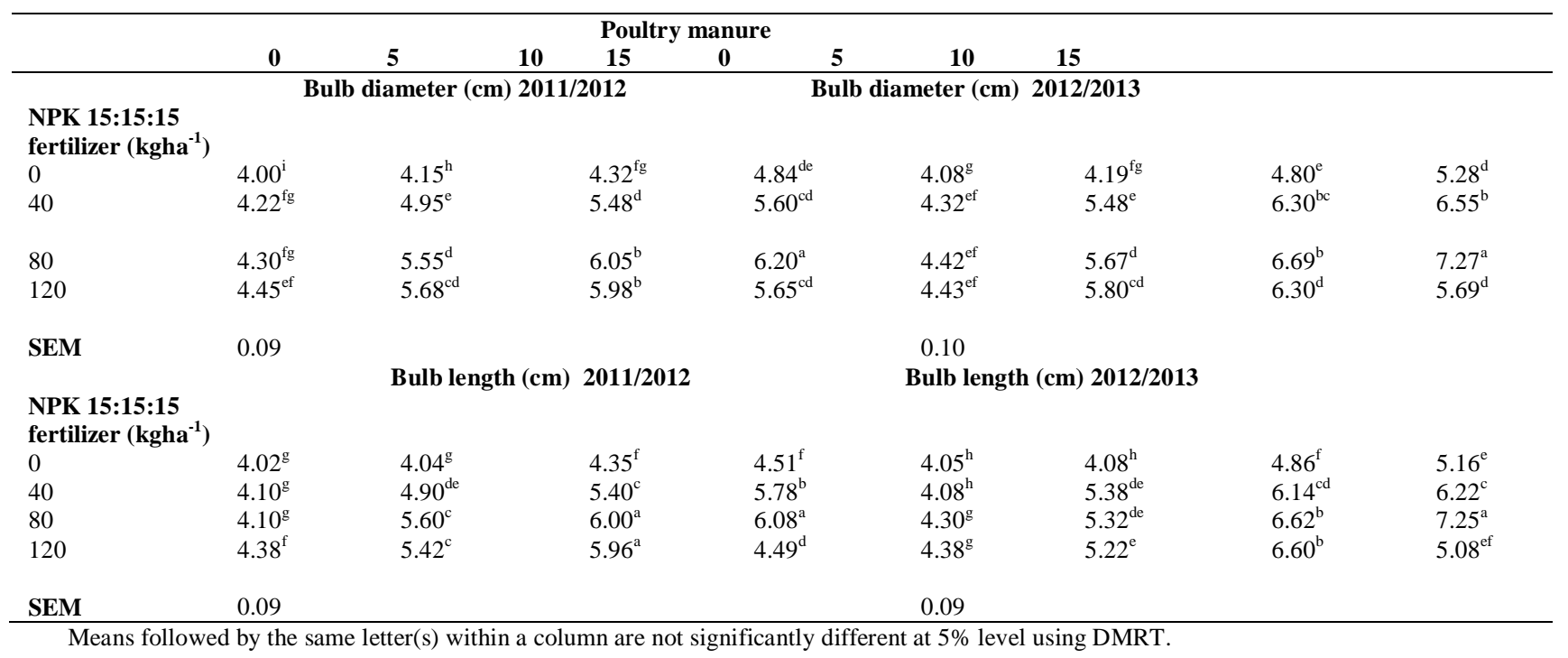


Table 5: Interactions between NPK 15:15:15 fertilizer and poultry manure on yield of onion (2011/2012) and 2012/2013 dry cropping season

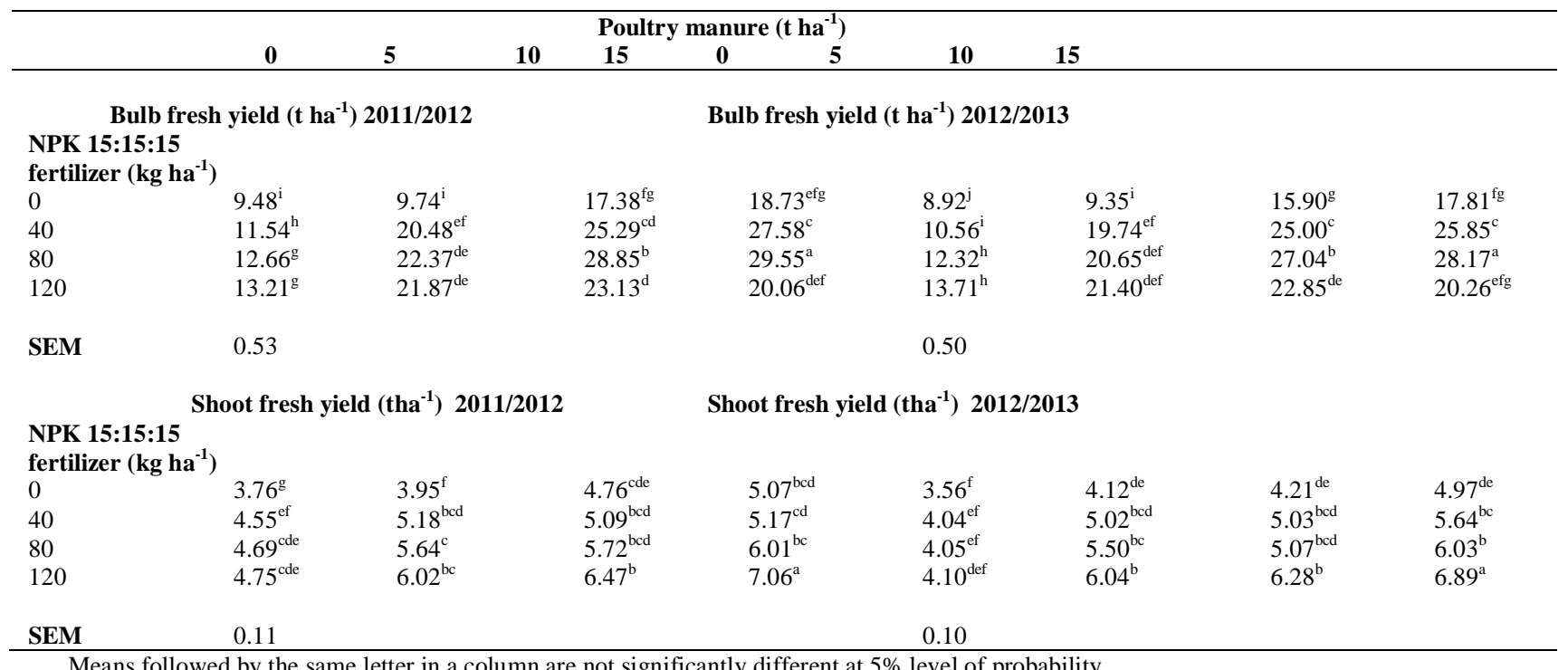

Means followed by the same letter in a column are not significantly different at $5 \%$ level of probability.

\section{Bulb diameter and length}

The effect of inorganic fertilizer on bulb diameter and length was highly significant. There was increase in bulb diameter and length up to 80 $\mathrm{kg} \mathrm{ha}^{-1}$, a further increase to $120 \mathrm{~kg} \mathrm{ha}^{-1} \mathrm{NPK}$, did not result in a significant increase. On the other hand, the effect of poultry manure was also highly significant. Plants treated with either 10 or 15 tha $^{-1}$ poultry manure were at par and significantly increased above the $5 \mathrm{t} \mathrm{ha}^{-1}$ and no manure application treatment (control). However, 5 tha $^{-1}$ poultry manure significantly increased bulb diameter and length above the control which produced the least values. The NPK X poultry manure interactions was highly significant. In Table 4 when the same NPK level was examined across the poultry manure levels, it was observed that at $0 \mathrm{kgha}^{-1}$ NPK $15 \mathrm{t} \mathrm{ha}^{-1}$ significantly increased bulb diameter above the other treatments with 5 and $10 \mathrm{t} \mathrm{ha}^{-1}$ poultry manure producing similar bulb diameter but higher than the control. At $40 \mathrm{~kg} \mathrm{ha}^{-1}$ NPK, bulb diameter increased with increase in poultry manure up to 10 tha $^{-1}$, with 10 and $15 \mathrm{tha}^{-1}$ producing similar bulb diameter and significantly higher than $5 \mathrm{tha}^{-1}$ and the control. At $80 \mathrm{~kg} \mathrm{ha}^{-1}$ NPK highest bulb diameter was produced at $15 \mathrm{tha}^{-1}$, followed by $10 \mathrm{t} \mathrm{ha}^{-1}$ then 5 tha ${ }^{-1}$, the control produced the least bulb diameter. At $120 \mathrm{~kg} \mathrm{ha}^{-1} \mathrm{NPK}$, bulb diameter increased up to $5 \mathrm{t} \mathrm{ha}{ }^{-1}$ poultry manure and a further increase in poultry manure did not affect bulb diameter.
When the same poultry manure level was examined across the NPK level, it was observed that at 0 poultry manure, 40,80 and $120 \mathrm{~kg} \mathrm{ha}^{-1}$ NPK produced similar bulb diameters, but were significantly increased above the control. At $5 \mathrm{t} \mathrm{ha}^{-}$ ${ }_{1}^{1}$ poultry manure, bulb diameter increased up to 80 $\mathrm{kg} \mathrm{ha}^{-1}$ producing similar bulb diameter as $120 \mathrm{~kg}$ $\mathrm{ha}^{-1}$ (Table 4). At $10 \mathrm{t} \mathrm{ha}^{-1}$ poultry manure, increase in NPK fertilizer up to $40 \mathrm{~kg} \mathrm{ha}^{-1}$ significantly increased bulb diameter, with 40 and $80 \mathrm{~kg} \mathrm{ha}^{-1}$ NPK producing similar bulb diameter but significantly increased above the control and $120 \mathrm{~kg} \mathrm{ha}^{-1}$ NPK. At $15 \mathrm{t} \mathrm{ha}^{-1}$ highest bulb diameter was produced at $80 \mathrm{~kg} \mathrm{ha}^{-1}$ NPK, followed by $40 \mathrm{~kg} \mathrm{ha}^{-1}$ NPK. The least bulb diameter was produced at the control and $120 \mathrm{~kg}$ $\mathrm{ha}^{-1}$ NPK treatments which produced similar bulb diameter. When the same level of NPK was examined across the poultry manure level, it was observed that at $0 \mathrm{~kg} \mathrm{ha}^{-1}$, bulb length increased up to $10 \mathrm{t} \mathrm{ha}^{-1}$ producing similar value with $15 \mathrm{t} \mathrm{ha}^{-1}$. At $40 \mathrm{~kg} \mathrm{ha}^{-1} \mathrm{NPK}$, each increase in poultry manure increased bulb length from 0 to $15 \mathrm{t} \mathrm{ha}^{-1}$. At $80 \mathrm{~kg}$ ha ${ }^{-1} \mathrm{NPK}$, bulb length increased significantly with increase in poultry manure up to $10 \mathrm{t} \mathrm{ha}^{-1}$. A further increase in the rate of poultry manure to 15 $\mathrm{t} \mathrm{ha}^{-1}$ did not affect bulb length. At $120 \mathrm{~kg} \mathrm{ha}^{-1}$ NPK, bulb length increased with increase in poultry manure up to $10 \mathrm{t} \mathrm{ha}^{-1}$ and a further increase in poultry manure decreased the bulb length. 
When the same level of poultry manure was examined across the NPK levels, it was observed that at 0 tha $^{-1}$ poultry manure bulb length was the same from 40 to $80 \mathrm{~kg} \mathrm{ha}^{-1}$ NPK and increased at $120 \mathrm{~kg} \mathrm{ha}^{-1}$. At 5 tha $^{-1}$ poultry manure, bulb length increased significantly from 0 to $80 \mathrm{~kg} \mathrm{ha}^{-1}$ NPK. A further increase in NPK to $120 \mathrm{~kg} \mathrm{ha}^{-1}$ did not affect the bulb length. At 10 and 15 tha $^{-1}$ poultry manure, each increase in NPK fertilizer increased the bulb length up to $80 \mathrm{~kg} \mathrm{ha}^{-1}$ NPK. A further increase to $120 \mathrm{~kg} \mathrm{ha}^{-1}$ decreased the bulb length significantly. The highest bulb length was produced at either 10 or $15 \mathrm{t} \mathrm{ha}^{-1}$ poultry manure in combination with $80 \mathrm{~kg} \mathrm{ha}^{-1}$ NPK.

\section{Bulb yield}

The inorganic fertilizer $\mathrm{X}$ poultry manure was highly significant. In Table 5, when the same level of NPK was examined across the poultry manure, it was observed that at $0 \mathrm{~kg} \mathrm{ha}^{-1} \mathrm{NPK}$, bulb yield increased with increase in poultry manure up to $10 \mathrm{tha}^{-1}$ and a further increase to $15 \mathrm{t}$ $\mathrm{ha}^{-1}$ did not affect the bulb yield. At 40 and $80 \mathrm{~kg}$ $\mathrm{ha}^{-1} \mathrm{NPK}$, bulb yield increase with each increase in poultry manure up to $15 \mathrm{t} \mathrm{ha}^{-1}$. At $120 \mathrm{~kg} \mathrm{ha}^{-1}$ NPK, bulb yield increased up to $5 \mathrm{t} \mathrm{ha}^{-1}$ poultry manure and a further increase in poultry manure did not affect the bulb yield of onion.

When the same level of poultry manure was examined across the NPK levels, it was observed that at 0 and $5 \mathrm{t} \mathrm{ha}^{-1}$ poultry manure, bulb yield was increased from 0 to $40 \mathrm{~kg} \mathrm{ha}^{-1}$ NPK and a further increase in NPK level did not affect the bulb yield. At 10 and $15 \mathrm{t} \mathrm{ha}^{-1}$ poultry manure, each increase in NPK fertilizer significantly increased the bulb yield of onion up to $80 \mathrm{~kg} \mathrm{ha}^{-1}$ NPK. A further increase to $120 \mathrm{~kg} \mathrm{ha}^{-1}$ NPK decreased the bulb yield significantly. The highest bulb yield was produced at $80 \mathrm{~kg} \mathrm{ha}^{-1} \mathrm{NPK}$ in combination with $15 \mathrm{tha}^{-1}$ poultry manure.

\section{Shoot yield}

The inorganic $X$ poultry manure interaction was highly significant. In Table 5, when the same level of NPK was examined across the poultry manure, it was observed that at all levels of NPK, shoot yield increased with increase in poultry manure up to $15 \mathrm{t} \mathrm{ha}^{-1}$ with 5 and $10 \mathrm{t}$ $\mathrm{ha}^{-1}$ poultry manure producing similar shoot yield, but $15 \mathrm{tha}^{-1}$ poultry manure significantly increased shoot yield above all other treatments. When the same level of poultry manure was examined across the NPK levels, it was observed that at 0 tha $^{-1}$ poultry manure, shoot yield increased from 0 to 40 $\mathrm{kg} \mathrm{ha}^{-1}$ NPK and a further increase did not affect the shoot yield. At $5 \mathrm{t} \mathrm{ha}^{-1}$ poultry manure, shoot yield increased with increase in fertilizer with similar shoot yield produced at 40 and $80 \mathrm{~kg} \mathrm{ha}^{-1}$ NPK, but a further increase to $120 \mathrm{~kg} \mathrm{ha}^{-1}$ NPK significantly increased shoot yield above other treatments. At 15 tha $^{-1}$ poultry manure shoot yield increased significantly with each increase in poultry manure up to $15 \mathrm{t} \mathrm{ha}^{-1}$. The highest shoot was produced at $120 \mathrm{~kg} \mathrm{ha}^{-1}$ in combination with $15 \mathrm{tha}^{-1}$ poultry manure.

\section{DISCUSSION}

The increase in leaf length of onion as a result of combine use of fertilizers indicated that onion plants responded positively to combined use of organic and inorganic fertilizers. The quick response to combine use of fertilizer by onion plant may be due to the fact that fertilizers mineralized quickly, releases its nutrients to crop faster and eventually leached beyond the root zone of crops and organic manure in combination complements this effect by exerting their effect for a longer periods compared to sole application of these fertilizer thereby resulting in better crop growth and yield of the crop.

Number of leaves per plant and stem diameter increased significantly as a result of combine application of both organic and inorganic fertilizer. Inorganic fertilizer treated plant exhibited quick growth of leaves and stem diameter at the early stage. The rate of release of nutrients were much higher in the inorganic fertilizers since they provided major elements at the early stage of plant growth and development. Thus, plants exhibited accelerated growth rate than poultry manure. Babajide et al (2008) in their work on onion stated that relatively high levels of nutrients are required for optimum growth and development at the early stage of growth. In poultry manure, nutrients element content are low and the nutrient are not readily available for plant uptake. In this present study, plants treated with poultry manure alone showed reduced number of leaf production at the early stage of growth. At the later stage of growth, leaf and stem diameter growth, was almost similar to the growth rate observed with the inorganic fertilizer treated plants, this observation could be linked to the slow availability of nutrients from the poultry manure at the early stage. Thus inorganic hasten early growth of onions, but that could recompense by the organic manure in the later stages.

Combined application of organic and inorganic fertilizer enhances the bulb formation in onion. Combined applied treatments produced larger bulbs per plants than sole application of inorganic fertilizer or organic fertilizer. Bulb 
formation of onion could be affected by soil structure at the time of bulb initiation in order to enhance larger bulbs per plant, addition of organic manure to inorganic fertilizer is needed to increase soil organic matter content, activates soil micro and macro organisms and improves the soil structure. Babajide et al (2008) stated that combine application of organic and inorganic fertilizer gave better results than their sole application in onion production, they emphasized that high and sustainable crop yield can be obtained with judicious use of combine application The crop growth rate, chlorophyll content, increased with increase in application of inorganic fertilizer Control plot produced the lowest values for bulb yield of onion, due to the absence of inadequate nutrient level which is an important factor needed for proper growth and development of every plant including onion.

\section{CONCLUSION}

Generally, these results showed that onion plants responded to lower rates of inorganic fertilizer in combination with higher rates of poultry manure for optimum bulb yield while higher rates of both inorganic and organic fertilizers in this study favoured shoot yield. The trend of increasing tendency for vegetable production can be sustained through combined use of organic manure and mineral fertilizers in order to optimized plant nutrition and obtain high yields and good quality of vegetable products. The use of combined application of organic and inorganic fertilizer reduces the dependence of the farmer on inorganic fertilizer use. It also reduces the exposure of the soil to the consequences of inorganic fertilizer application and also would reduce the cost of mineral fertilizers. From this study, it can therefore be concluded that higher total bulb yield could be obtained by applying 40 or $80 \mathrm{~kg} / \mathrm{ha}$ of NPK $15: 15: 15$ in combination with 10 or 15 t/ha poultry.

\section{ACKNOWLEDGEMENT}

The authors acknowledges STEP-B (World Bank/ Federal Ministry of Education) and University of Benin, Benin City Nigeria for the research grant to complete the work.

\section{REFERENCES}

Akoun, J. (2004). Effect of plant density and manure on the yield and yield components of the common onion (Allium cepa L.) var. Nsukka red, Nigeria Journal of Horticultural Sciences 9: 43-48.

AL - Tarawneh, A. A., (2005). The effects of two types of organic manure and NPK on growth, yield and quality of lettuce and strawberry. M.Sc. Thesis, Mu'tah university, Jordan $169 \mathrm{pp}$.

Arisha H. M. and Bradisi, A. (1999). Effect of mineral fertilizers and organic fertilizers on growth, yiled and quality of potato under sandy soil conditions. Zagazig Journal of Agricultural Research 26: 391 -405 .

Babajide,

P.A.,Olabode,O.S.,Akanbi,W.B.,Olatunji, O.O and Ewetola,E.A. (2008). Influence of composted Tithonia N-biomass and NMineral fertilizer on soil physicochemical properties and performance of tomatoes (Lycopersicum esculentus). Research Journal of Agronomy, 2 (4) : 101-106

Bayu W., Rethman N.F.G., Hammes, P.S and Alemu, G. (2006). Effects of farmyard manure and

inorganic fertilizer on sorghum growth, yield and nitrogen use in a Semi - Arid Area of Ethopia.

Journal of Plant Nutrition, $29: 391-407$.

Bray, R.H. and Kurtz, L.T. (1945). Determination of total organic and available forms of $\mathrm{P}$ in soils. Soil Science, 59:39 - 45.

Colla, G., Mitchell. J., Poudel, D. and Temple, S. (2002). Changes of tomatoes yield and fruit elemental composition in conventional, low input, and organic systems. Journal of sustainable Agriculture 20 (2) : 53-67.

Dobermann A, Cassman K. G. (2004). Environmental dimensions of fertilizer nitrogen: What can be done to increase nitrogen use efficiency and ensure global food security. In: Mosier A R, Syers J K Freney J R, editors. Agriculture and the nitrogen cycle: Assessing the impact of fertilizer use on food production and the environment (SCOPE 65). London: Island Press $278 \mathrm{pp}$.

International Atomic Energy Agency (IAEA). (2003). Management of crop residues for sustainable crop production. IAEA Techdoc - 1354. Vienna: IAEA.

Jackson, M.L. (1969). Soil Chemical Analysis. Constable and Co Ltd, London, U.K. 132 pp.

Jeyarani, P. (1986). A study of feasibility of regulating water retention capacity of sandy regosol. A report of B. Sc. (Agric.) Thesis. Eastern University of Srilanka 24pp. 
Jeyathilake, P.K.S., Reddy, I.P., Srihari, D. and Reddy, K.R. (2006). Productivity and soil fertility status as influenced integrated use of N-Fixing Biofertilizers, organic manures and inorganic fertilizers in onion. Journal of agricultural science, 2(1):46-58.

Krupnik T. J., Six J., Ladha J.K., Paine M.J. and Van Kessel, C. (2004). An assessment of fertilizer nitrogen recovery by grain crops. In: Mosier A R, Syers JK, Freney JR, editors. Agriculture and the nitrogen cycle: assessing the impacts of fertilizer use on food production and the environment (SCOPE 65). London: Island Press. pp 193 - 208.

Murphy, J. and Riley, J.P (1962). Modified. single solution methods for determination of phosphorus in natural water. Analytical Chemistry Acta 27:31 -36.

Ouda, B.A and Mahajeen, A.Y (2008). Effect of fertilizers on growth, yields and yield components, quality and certain nutrients contents in Broccoci. (Brassica oleracea). International Journal of Agriculture and Biology 10 (16): 627-632.
Paul G. C, and Manna M.A. (2006). Integrated nutrient management in sugar cane to enhance sugar productivity in: proceedings, international symposium on Technologies to improve sugar productivity in developing countries; Guilin, People's Republic of China. Pp. $108-121$.

Rumple .J. (1998). Effect of long term organic mineral and combined organic - mineral fertilization on yield of onions (Allium cepa L.) grown from seeds. Biuletyn Warzniczy 48: 5 - 15.

Sharma, R. P., Datt, N. and Sharma P. K. (2003). Combined application of Nitrogen, Phosphorus; Potassium and Farm yard manure in Onion under High Hills, Dry Temperate conditions of North - Western Himalayas. Indian Journal of Agricultural Science 73: 4: 225 - 227. 